\title{
Human B Lymphoma Cell Line Producing B Cell Growth Factor
}

\author{
Julian L. Ambrus, Jr., and Anthony S. Fauci \\ Laboratory of Immunoregulation, National Institute of Allergy and Infectious Diseases, \\ National Institutes of Health, Bethesda, Maryland 20205
}

\begin{abstract}
Namalva, a human B cell lymphoma line, produced a factor with a molecular weight of $\sim 60,000$ which enhanced the proliferation of normal activated human $B$ lymphocytes. The factor also enhanced the proliferation of certain $B$ cell lines. It can be distinguished physiologically and biochemically from other lymphokines known to enhance B cell proliferation, namely, interleukin (IL) 1, IL 2, and interferon. The production of B cell growth factor by B cell tumor lines may contribute to their ability to grow autonomously and may reflect an important component of the neoplastic potential of the cell. B cell growth factor produced by tumors may also affect normal cells in vivo.
\end{abstract}

\section{Introduction}

Regulation of the immune response is dependent upon the complex interactions of lymphocyte and monocyte subsets and a variety of cell-derived soluble factors. It has been clearly demonstrated that $\mathrm{T}$ lymphocytes produce lymphokines that cause activated B lymphocytes to proliferate: this factor has been termed B cell growth factor (BCGF) ${ }^{1}$ (1). Furthermore, distinct lymphokines act on the proliferating $B$ cells to induce them to differentiate (2). The source of BCGF in human studies has been claimed to be one of the following: mitogenstimulated unfractionated peripheral lymphocytes, $\mathrm{T}$ cell clones (3), or T-T hybridomas (4). Long-term growth of nonmalignant and non-Epstein-Barr virus (EBV)-transformed B lymphocytes has been claimed to be dependent upon BCGF (5). Blazar et al. (6) and Gordon et al. (7) have described autostimulatory activity produced by EBV-transformed B cell lines. Gordon et al. (8) also demonstrated the ability of the EBV-transformed $B$ cell line supernatants to stimulate the proliferation of normal tonsillar B cells, although they did not fully characterize biochemically the substance responsible for this BCGF-like activity and did not distinguish it from other lymphokines such as interferon, interleukin (IL) 1, and IL 2. To our knowledge, the production of BCGF, distinct from other known lymphokines, by human B cell lines capable of acting on normal cells has not been demonstrated. The diffuse

\section{Address all correspondence to Dr. Ambrus. \\ Received for publication 25 April 1984 and in revised form 10 October 1984.}

1. Abbreviations used in this paper: $\mathrm{BCDF}, \mathrm{B}$ cell differentiation factor; BCGF, B cell growth factor; Con A, concanavalin A; EBV, EpsteinBarr virus; FACS, fluorescence-activated cell sorter; FCS, fetal calf serum; IL, interleukin; LPS, lipopolysaccharide; PHA, phytohemagglutinin; PMA, phorbol myristic acetate; SAC, Staphylococcus aureus Cowan I.

The Journal of Clinical Investigation, Inc.

Volume 75, February 1985, 732-739 immunologic abnormalities associated with leukemias and lymphomas may be due to the production of lymphokines by the tumors that can act on normal cells.

In our study, we demonstrate the physiologic and partial biochemical characteristics of BCGF produced by Namalva, a human Burkitt's lymphoma line, upon stimulation with phytohemagglutinin (PHA). We further demonstrate that certain other B cell lines constitutively produce factors with BCGFlike activity.

\section{Methods}

Cell lines. The cell line Namalva has been maintained in our laboratory for several years. B cell lines BALM-1, BALM-4, and BALL-1, and T cell lines Molt-4 and T-ALL were kindly provided by Dr. Jun Minowada, Loyola University, Chicago, IL. Ball-1S and Ball-1A5 are subclones of BALL-1 produced by plating BALL-1 at 1 cell/well. After $3 \mathrm{wk}$, positive wells were screened for responsiveness to BCGF. Ball1A5 showed increased $\left[{ }^{3} \mathrm{H}\right]$ thymidine incorporation in response to BCGF while Ball-1S showed decreased $\left[{ }^{3} \mathrm{H}\right]$ thymidine incorporation in response to BCGF. Ball-1A5 was then maintained in medium containing $10 \% \mathrm{vol} / \mathrm{vol}$ BCGF. 3B3, a human T-T hybridoma, which was developed in our laboratory, produces BCGF in the absence of IL 2 or $B$ cell differentiation factor (BCDF) activity (4). The characteristics of a BCGF produced by a subclone of $3 B 3,2 B_{11}$, have been previously reported (9).

Media. Cell lines were grown in RPMI 1640 supplemented with $10 \%$ fetal calf serum (FCS; Dutchland Laboratories, Inc., Denver, PA), penicillin $(100 \mu \mathrm{g} / \mathrm{ml})$, streptomycin $(100 \mu \mathrm{g} / \mathrm{ml})$, and amphotericin $(2$ $\mu \mathrm{g} / \mathrm{ml}$ ) (Fungizone; Flow Laboratories, Inc., McLean, VA). Cell lines used for factor production were adapted to growth in complete $\mathrm{HBlO2}$ (HANA Media, Inc., Berkeley, CA) without FCS.

Reagents. Anti- $\mu$ is the $\mathrm{F}\left(\mathrm{ab}^{\prime}\right)_{2}$ fragment of goat antihuman heavy chain-specific IgM (Cappel Laboratories, Cochranville, PA). Staphylococcus aureus Cowan I (SAC) was prepared in our laboratory as previously described (10). PHA was obtained from Wellcome Research Laboratories (Beckenham, England). Concanavalin A (Con A), phorbol myristic acetate (PMA), and neuraminidase were obtained from Sigma Chemical Company (St. Louis, MO). Lipopolysaccharide (LPS; Escherichia coli $0-128: B 12$ LPS) was obtained from Difco Laboratories, Inc. (Detroit, MI). Bolton-Hunter reagent was obtained from New England Nuclear (Boston, MA).

Cell surface staining. The monoclonal antibodies Leu-1, Leu-10, Leu-12, and anti-DR were obtained from Becton-Dickinson \& Co. (Sunnyvale, CA). OKT3, antihuman Ig, and fluorescein isothiocyanateconjugated goat antimouse IgG were obtained from Ortho Diagnostic Systems, Inc. (Westwood, MA). Antimonocyte 0.2 was obtained from Bethesda Research Laboratories (Gaithersburg, MD). Cells were stained with the appropriate antibody, counterstained with fluorescein isothiocyanate-conjugated goat antimouse IgG, and then examined with the fluorescence-activated cell sorter (FACS) (B-D FACS Systems; BectonDickinson \& Co.). Cell staining was scored as positive if more than a $50 \%$ increase over background staining was noted.

Cell preparation. B lymphocytes for use in BCGF assays were obtained from human tonsils by dispersing the tonsils into single cell suspensions and separating the mononuclear cells by gradient centrifugation over Ficoll-Hypaque (Pharmacia Fine Chemicals, Div. of 
Pharmacia, Inc., Piscataway, NJ). T cells were depleted by rosetting them twice with aminoethylisothiouronium bromide-treated sheep erythrocytes as previously described (11). Monocytes were depleted by adhering them to plastic flasks (model 25116; Corning Glass Works, Corning Medical and Scientific, Corning, NY) in RPMI 1640 with $1 \%$ FCS for $60 \mathrm{~min}$ at $37^{\circ} \mathrm{C}$. Small and large populations of B cells were separated from the B cell-enriched population by counterflow centrifugation-elutriation as previously described (12).

Preparation of factors. Cell lines were grown at a concentration of $1 \times 10^{6} \mathrm{cells} / \mathrm{ml}$. Mitogen stimulation consisted of the addition of 1 $\mu \mathrm{g} / \mathrm{ml}$ PHA, $10 \mu \mathrm{g} / \mathrm{ml}$ Con A, $5 \mathrm{ng} / \mathrm{ml}$ PMA, or $10 \mu \mathrm{g} / \mathrm{ml}$ LPS $3 \mathrm{~d}$ before harvesting the cell-free supernatant. Factor for purification was produced by cells grown in RPMI without added protein for $72 \mathrm{~h}$ with PHA.

$B C G F$ assays. BCGF activity was measured by using both the anti$\mu$ costimulator assay (12) and the SAC assay (10). Briefly, in the anti$\mu$ assay, B cell-enriched cells were distributed into 96-well flat-bottomed microtiter plates (Costar 3596; Data Packaging Corp., Cambridge, MA) at $10^{5}$ cells/well in a total volume of $0.2 \mathrm{ml}$. Anti- $\mu(15 \mu \mathrm{g} / \mathrm{ml})$, anti- $\mu$ plus factor $(25 \% \mathrm{vol} / \mathrm{vol})$, or cells alone were cultured for $72 \mathrm{~h}$ in $7 \%$ $\mathrm{CO}_{2}$ in air at $37^{\circ} \mathrm{C}$ in $100 \%$ humidity. Over the last $16 \mathrm{~h}$ of the $72-\mathrm{h}$ culture period, $1 \mu \mathrm{Ci}$ of $\left[{ }^{3} \mathrm{H}\right]$ thymidine (New England Nuclear) was added to the culture wells. Cells were then harvested using a Skatron cell harvester (Flow Laboratories, Inc., McLean, VA), and the incorporation of $\left[{ }^{3} \mathrm{H}\right]$ thymidine was measured by standard liquid scintillation counting techniques. In the SAC assay, B cell-enriched cells were stimulated with SAC at a dilution of $1: 25,000$ and placed into culture as described above. Factor for purification was added to the appropriate wells at $72 \mathrm{~h}$, and wells were pulsed with $1 \mu \mathrm{Ci}\left[{ }^{3} \mathrm{H}\right]$ thymidine for the last $16 \mathrm{~h}$ of the $144 \mathrm{~h}$ culture period. Cells were then harvested, and incorporation of $\left[{ }^{3} \mathrm{H}\right]$ thymidine was measured as described above.

$B C G F$ activity using cell lines. Cells from the responding B cell lines were plated at $10^{5}$ cells/well in a total volume of $0.2 \mathrm{ml}$ in 96 well microtiter plates. Factor for purification was added at $25 \% \mathrm{vol} /$ vol in the appropriate wells, and the cells were cultured for $72 \mathrm{~h}$ in $7 \% \mathrm{CO}_{2}$ in air at $37^{\circ} \mathrm{C}$ and $100 \%$ humidity. Cells were pulsed with 1 $\mu \mathrm{Ci}\left[{ }^{3} \mathrm{H}\right]$ thymidine per well for the last $16 \mathrm{~h}$ and then harvested as described above.

Other lymphokine assays. The IL 1 assay was kindly performed by Dr. Theresa Gerrard as previously described (13). The interferon assay was performed by Biofluids, Inc. (Rockville, MD) as described (14). Assessment of B cell differentiation activity of factors was assessed on SAC-activated B cells as discussed (10). The IL 2 assay was performed as previously described (15) using the IL 2-dependent T cell line HT2 (kindly provided by Dr. David Volkman, National Institutes of Health).

Gel filtration. Supernatant from Namalva cells $(1,000 \mathrm{ml})$ that had been stimulated with PHA was concentrated to $4 \mathrm{ml}$ by filtration using a YM10 membrane (Amicon Corp. Scientific Sys. Div., Danvers, MA). Half of the concentrated supernatant was applied to a Sephadex G100 gel filtration column $(90 \times 2 \mathrm{~cm}$; Pharmacia Fine Chemicals). The other half of the concentrated supernatant was treated with $5 \mathrm{U} /$ $\mathrm{ml}$ of neuraminidase for $12 \mathrm{~h}$ at $37^{\circ} \mathrm{C}$ before being applied to the column. The column was eluted with phosphate-buffered saline (HEM
Laboratories, Rockville, MD) at a flow rate of $10 \mathrm{ml} / \mathrm{h} ; 3.0-\mathrm{ml}$ fractions were collected.

Isoelectric focusing. Isoelectric focusing was performed in a 20 $\times 11 \times 0.5 \mathrm{~cm}$ preparative focusing bed (Bio-Rad Laboratories, Richmond, CA) using Pevikon (Accurate Chemical \& Scientific Corp., Westbury, NY). Briefly, $112 \mathrm{~g}$ of Pevikon was washed three times in distilled water and then allowed to dry. The Pevikon was then saturated with $52 \mathrm{ml}$ of a 1:10 solution of 3.5-10 ampholytes (LKB, Instruments, Inc., Gaithersburg, MD) in distilled water and placed in the focusing bed. Active fractions of the supernatant from PHA-stimulated Namalva, obtained from the G-100 column, were applied in the middle of the focusing bed. This was done separately for neuraminidase-treated and - untreated Namalva supernatant. An electrical current was applied across the bed at a constant power of $5 \mathrm{~W}$. Focusing was completed when $1,000 \mathrm{~V}$ were attained. The bed was then sliced and individual sections placed in $10 \mathrm{ml}$ of distilled water and refrigerated at $4^{\circ} \mathrm{C}$ overnight. The $\mathrm{pH}$ of each section was measured and the samples were spun down at $600 \mathrm{~g}$ for $30 \mathrm{~min}$. The supernatants were pipetted off and dialyzed against RPMI 1640 for $48 h$ at $4^{\circ} \mathrm{C}$. Individual samples were concentrated by filtration using a PM5 membrane (Amicon Corp. Scientific Sys. Div.) to a total volume of $1 \mathrm{ml}$. These fractions were then assayed for BCGF activity.

Isoelectric focusing of $\mathrm{I}^{125}$-labeled purified Namalva factor was done in a $6 \%$ acrylamide gel with $0.05 \%$ ampholytes. The sample was applied with a $0.5 \times 2 \mathrm{~cm}$ wick resting on the gel. A current was applied across the gel at a constant power of $5 \mathrm{~W}$. Focusing was completed when $800 \mathrm{~V}$ was attained. The gel was then sliced and the $\mathrm{I}^{125}$ retained in each slice was assessed with a gamma counter. $1 \mathrm{ml}$ distilled water was added to each fraction. $2 \mathrm{~h}$ later, the $\mathrm{pH}$ of each fraction was measured.

Purification of Namalva (factor). Purification of Namalva (factor) was accomplished by starting with 5 liters of PHA-stimulated Namalva supernatant grown for $72 \mathrm{~h}$ in RPMI without added protein. The supernatant was concentrated 100 -fold by Amicon filtration using a YM10 membrane. The concentrated factor was then subjected to ion exchange chromatography using DEAE-Sepharose (Pharmacia Fine Chemicals) and a salt gradient of $5-300 \mathrm{mM}$. Active fractions were subjected to G-100 sieving and then isoelectric focusing as described above. Active fractions from isoelectric focusing were pooled and labeled with $\mathrm{I}^{125}$ using Bolton-Hunter reagent by a standard procedure (16).

Sodium dodecyl sulfate (SDS)-polyacrylamide gel electrophoresis. $I^{125}$-labeled Namalva (factor) was analyzed by electrophoresis on a $10 \%$ polyacrylamide gel in 1\% SDS (17). Molecular weight standards (BioRad) were run simultaneously. The gel was then dried and molecular weight markers labeled with an autoradiography marker (Ultemit; New England Nuclear). Autoradiography of the entire gel was then performed.

\section{Results}

Characteristics of cell lines. The cell surface staining characteristics of the cell line were examined using an FACS (Table I). Namalva was indeed found to be a B cell line as it expressed

Table I. Surface Staining by FACS of B and T Lymphoma Lines

\begin{tabular}{|c|c|c|c|c|c|c|c|c|}
\hline Cell line & Surface Ig & Leu-1 & Leu-10 & Leu-12 & OKT3 & DR & Antimonocyte 0.2 & EBNA \\
\hline Namalva & + & - & + & + & - & + & - & + \\
\hline BALM-1 & + & - & ND & + & - & ND & - & + \\
\hline BALM-4 & + & - & ND & + & - & ND & - & - \\
\hline BALL-1 & + & - & ND & + & - & ND & - & $\mathrm{ND}^{*}$ \\
\hline Molt-4 & - & + & - & - & + & ND & - & ND \\
\hline
\end{tabular}

ND, not done. * Reported by Dr. Jun Minowada to be Epstein-Barr nuclear antigen (EBNA) negative. 
surface Ig, Leu-10, Leu-12, and DR antigens. Staining for Leu1, OKT3, and antimonocyte 0.2 was negative. Epstein-Barr nuclear antigen staining was positive in Namalva and negative in BALM-4 in several separate assays (kindly performed by Gary Armstrong, Food and Drug Administration). EpsteinBarr nuclear antigen staining of BALL-1 was reported to us as negative by Dr. Minowada. Molt 4, a well-established $\mathrm{T}$ cell line, was used here as a control.

Namalva was evaluated for possible mycoplasma contamination by the Mycotrim culture system (HANA Media, Inc.) as well as by $\left[{ }^{3} \mathrm{H}\right]$ thymidine incorporation into the cell supernatant, indicating the presence of mycoplasma (18). Both of these assays were negative.

Supernatants from cell lines. The supernatant from unstimulated Namalva contained little, if any, BCGF activity (Table II). When Namalva was stimulated with PHA, however, the supernatant (designated Namalva [factor]) demonstrated substantial BCGF activity in that it significantly enhanced $\left[{ }^{3} \mathrm{H}\right]$ thymidine incorporation of anti- $\mu$ or SAC-activated human tonsillar B lymphocytes. This BCGF activity was comparable to that produced by PHA-stimulated T-ALL or unstimulated

Table II. BCGF Activity of Various Cell Line Supernatants Demonstrated on Unfractionated B Cells

\begin{tabular}{llc}
\hline Stimulus & Factor added & $\begin{array}{c}\text { [ }^{3} \mathrm{H} \text { Thymidine } \\
\text { incorporation }\end{array}$ \\
\hline & & $c p m$ \\
\hline Anti- $\mu^{*}$ & - & $167 \pm 23$ \\
SAC $\ddagger$ & - & $471 \pm 18$ \\
Anti- $\mu$ & PHA§ & $797 \pm 47$ \\
Anti- $\mu$ & Namalva (unstimulated) & $184 \pm 7$ \\
SAC & Namalva (unstimulated) & $730 \pm 15$ \\
Anti- $\mu$ & Namalva (factor) & $957 \pm 84$ \\
SAC & Namalva (factor) & $17,645 \pm 1,487$ \\
Anti- $\mu$ & T-ALL (stimulated with & $7,592 \pm 125$ \\
& PHA) & $13,623 \pm 303$ \\
SAC & T-ALL (stimulated with & \\
& PHA) & $6,743 \pm 427$ \\
Anti- $\mu$ & 3B3T (unstimulated) & $22,516 \pm 630$ \\
SAC & 3B3 (unstimulated) & $8,240 \pm 221$ \\
Anti- $\mu$ & BALM-4 (unstimulated) & $140 \pm 17$ \\
Anti- $\mu$ & BALM-4 (stimulated with & $4,449 \pm 128$ \\
& PHA) & \\
Anti- $\mu$ & BALL-1S** (unstimulated) & $15,221 \pm 985$ \\
& & \\
\hline
\end{tabular}

This table shows data characteristic of several experiments. Some variability is seen in the absolute cpm $\left(\left[{ }^{3} \mathrm{H}\right]\right.$ thymidine incorporation) from experiment to experiment because of the difference in the various tonsils used.

* Anti- $\mu$ used at $15 \mu \mathrm{g} / \mathrm{ml}$.

$\ddagger$ SAC used at a dilution of $1: 25,000$.

$\S$ PHA used at $1 \mu \mathrm{g} / \mathrm{ml}$.

"Namalva (factor) is used to indicate the supernatant obtained from Namalva stimulated with PHA for $4 \mathrm{~d}$ at $1 \mu \mathrm{g} / \mathrm{ml}$.

『 $3 \mathrm{~B} 3$ is the supernatant from a T-T hybridoma selected for BCGF activity.

** BALL-1S is a clone of BALL-1 selected for decreased proliferation in response to exogenous BCGF.
3B3. BALM-4 produced less BCGF activity with PHA stimulation than that contained in Namalva (factor). BALL-1S, a clone of BALL-1 selected for decreased proliferation in response to exogenous BCGF, produced significant BCGF activity in the absence of PHA stimulation. PHA alone diminished rather than enhanced the proliferation of anti- $\mu$-stimulated B cells. Table III shows the dose-dependent BCGF activity of the factor produced by Namalva stimulated with PHA. Maximal BCGF activity is seen with $25 \%$ Namalva (factor), while $\sim 50 \%$ maximal BCGF activity occurs at $5 \%$ (vol/vol) Namalva (factor). The stimulation of Namalva with PMA, LPS, or Con A did not enhance BCGF activity beyond that of unstimulated Namalva (data not shown). The precise mechanisms whereby PHA induced the secretion of BCGF activity from Namalva is unclear. PHA did cause agglutination of the Namalva cells; Con A, however, also caused some agglutination (data not shown). PHA's major effect may be enhancing cell-cell interaction in such a way as to activate the cells. A more specific interaction with the cell surface membrane (or a receptor) is less likely given the fact that PHA is not mitogenic for human B cells.

The anti- $\mu$ assay appeared to be more sensitive than the SAC assay for detecting BCGF activity produced by Namalva. Therefore, we used it in evaluating the relative effects of Namalva (factor) on small (resting) B cells versus larger (activated) B cells (Table IV). Namalva (factor) clearly enhanced the proliferation of large B cells more than small B cells. This was similar to the factor produced by our $\mathrm{T}$ cell line. However, the BCGF produced by $3 \mathrm{~B} 3$ had a greater effect on small, anti- $\mu$-activated B cells. Costimulation of large B cells with anti- $\mu$ and Namalva (factor) did not increase the $\left[{ }^{3} \mathrm{H}\right]$ thymidine incorporation beyond what was seen when large $\mathrm{B}$ cells were stimulated with Namalva (factor) alone (data not shown). Interestingly, Namalva (factor) and 3B3 produced additive and occasionally synergistic effects on small B cells depending upon whether the response to $3 \mathrm{~B} 3$ was optimal or suboptimal. This synergy was also observed with large B cells but to a much lesser extent. Occasionally, the combination of $3 \mathrm{~B} 3$ and Namalva (factor) produced fewer counts than 3B3 alone. The exact mechanism of this variability is not clear but may be related to either the relative subpopulations or to activation states of the B cells obtained from the various tonsils. Relative numbers of contaminating $T$ cells or monocytes may also play a significant role in this variability. Namalva (factor), like the T-ALL supernatants, probably is more active at a later stage of B-cell proliferation than the supernatant from 3B3. Alternatively, Namalva (factor) and T-ALL supernatants may act on different subsets of $B$ cells than does the supernatant from 3B3.

Namalva (factor) could also enhance the proliferation of certain B cell lines (Table V). This was best demonstrated on BALL-1A5, a clone of BALL-1. BALL-1A5, selected for its ability to respond to $B C G F$, was grown in an exogenous source of BCGF. BALM-1, an EBV-positive B cell line with normally slow proliferation, did enhance its proliferation somewhat in the presence of Namalva (factor). Namalva (factor) generally had no effect or a slightly suppressive effect on the proliferation of Namalva cells, perhaps because Namalva was already responding to the factor it had produced. Furthermore, PHA present in Namalva (factor) had a slightly suppressive effect on the proliferation of Namalva cells. 
Table III. Dose Dependence of BCGF Activity Produced by PHA-stimulated Namalva Demonstrated on Anti- $\mu$-Stimulated Unfractionated B Cells

\begin{tabular}{ll}
\hline Factor added & {$\left[{ }^{3} \mathrm{H}\right]$ thymidine incorporation } \\
\hline & $\mathrm{cpm}$ \\
None & $6,113 \pm 889$ \\
PHA & $3,704 \pm 60$ \\
Namalva (factor)* 38\%(vol/vol) & $55,734 \pm 2,667$ \\
Namalva (factor) $25 \%(\mathrm{vol} / \mathrm{vol})$ & $54,734 \pm 1,577$ \\
Namalva (factor) $12.5 \%(\mathrm{vol} / \mathrm{vol})$ & $41,252 \pm 1,756$ \\
Namalva (factor) $5 \%(\mathrm{vol} / \mathrm{vol})$ & $20,050 \pm 2,474$ \\
Namalva (factor) $2.5 \%(\mathrm{vol} / \mathrm{vol})$ & $14,621 \pm 355$ \\
3B3 25\% (vol/vol $)$ & $33,564 \pm 606$ \\
3B3 2.5\% (vol $/ \mathrm{vol})$ & $12,358 \pm 404$ \\
\hline
\end{tabular}

These data are representative of several experiments. All B cells were stimulated with anti- $\mu$ at $15 \mu \mathrm{g} / \mathrm{ml}$.

* Namalva (factor) is the supernatant obtained from Namalva stimulated with PHA for $3 \mathrm{~d}$ at $1 \mu \mathrm{g} / \mathrm{ml}$.

$\ddagger 3 \mathrm{~B} 3$ is the supernatant from $\mathrm{T}$-T hybridoma selected for BCGF activity.

Since BCGF-like activity has been variably attributed to IL 1 (19), IL 2 (acting on contaminating $T$ cells to produce BCGF) (20), and interferon (21), attempts were made to distinguish Namalva (factor) from these lymphokines. No IL 1 activity was detected in Namalva (factor) using a mouse thymocyte assay (13). IL 2 activity was evaluated by assessing the effect of Namalva (factor) on the proliferation of an IL 2dependent cell line, HT-2; no activity was found. No interferon activity was detected in Namalva (factor) as determined by its ability to inhibit the proliferation of vesicular stomatitis virus in human amnion cells (14). Finally, BCDF activity of Namalva (factor) was assessed by measuring the production of $\mathrm{Ig}$ by SAC-activated B cells in the presence or absence of Namalva (factor). No enhancement of Ig production was noted in the presence of Namalva (factor) (data not shown).
Table V. Proliferation of $B$ Cell Lines

in Response to Namalva (Factor)

\begin{tabular}{llc}
\hline Cell line* & Factor added & {$\left[{ }^{3} \mathrm{H}\right]$ Thymidine incorporation } \\
\hline BALL-1A5 & None & $2,512 \pm 293$ \\
BALL-1A5 & PHA & $3,208 \pm 156$ \\
BALL-1A5 & Namalva (factor) & $6,228 \pm 28 \ddagger$ \\
BALM-1 & None & $427 \pm 66$ \\
BALM-1 & PHA & $238 \pm 57$ \\
BALM-1 & Namalva (factor) & $1,327 \pm 270 \S$ \\
& & $18,814 \pm 1,202$ \\
Namalva & None & $16,534 \pm 998$ \\
Namalva & PHA & $13,370 \pm 1,790$ \\
Namalva & Namalva (factor) &
\end{tabular}

* Responding B cell lines were used at a concentration of 100,000 cells/well in 96-well Costar plates.

$¥$ The difference between $2,512 \pm 293$ and $6,228 \pm 282$ is significant to $P<0.001$ ( $t$ test).

$\S$ The difference between $427 \pm 66$ and $1,327 \pm 270$ is significant to $P$ $<0.005$ ( $t$ test).

Crude biochemical characterization of Namalva (factor) revealed that it is trypsin sensitive, has a molecular weight of $\sim 60,000$, and has isoelectric points of 6.7 and 7.8. Molecular weight determination was made using a G-100 column. Fig. 1 shows that untreated Namalva (factor) had a high molecular weight activity peak (above the resolving capacity of the column, which is $100,000 \mathrm{~mol} w \mathrm{w}$ ) along with an additional activity peak of $\sim 60,000 \mathrm{~mol} \mathrm{wt}$. When concentrated Namalva (factor) was treated with neuraminidase, only the $60,000-\mathrm{mol}-$ wt activity peak remained. This finding suggests that the protein Namalva (factor) is heavily glycosylated and sialic acid residues may be important in the activity of the high molecular weight peak. Glycosylation of the BCGF may decrease the ability of the G-100 column to sieve it, perhaps by altering its tertiary structure. If, however, aggregation of the factor is

Table IV. Effect of Various BCGF on the Proliferation of Small and Large B Lymphocytes

\begin{tabular}{|c|c|c|c|c|}
\hline \multirow[b]{2}{*}{ Cells } & \multirow[b]{2}{*}{ Stimulus } & \multirow[b]{2}{*}{ Factor added } & \multicolumn{2}{|c|}{$\left[{ }^{3} \mathrm{H}\right]$ Thymiqine incorporation } \\
\hline & & & Exp. ! & Exp. 2 \\
\hline & & & $c p m$ & $c p m$ \\
\hline Small B cells & Anti- $\mu$ & - & $179 \pm 51$ & $581 \pm 15$ \\
\hline Small B cells & Anti- $\mu$ & PHA & $202 \pm 24$ & $375 \pm 61$ \\
\hline Small B cells & Anti- $\mu$ & Namalva (factor) & $2,194 \pm 238$ & $4,444 \pm 488$ \\
\hline Small B cells & Anti- $\mu$ & T-ALL & $2,130 \pm 303$ & $9,354 \pm 488$ \\
\hline Small B cells & Anti- $\mu$ & $3 \mathrm{~B} 3$ & $7,24 \hat{1} \pm 1,750$ & $16,703 \pm 1,328$ \\
\hline Small B cells & Anti- $\mu$ & 3 B3 + Namalva (factor) & $15,657 \pm 263$ & $11,831 \pm 1,130$ \\
\hline Small B cells & Anti- $\mu$ & $3 \mathrm{~B} 3+\mathrm{T}-\mathrm{ALL}$ & $11,426 \pm 491$ & $10,019 \pm 1,151$ \\
\hline Large B cells & - & - & $93 \pm 11$ & $1,239 \pm 51$ \\
\hline Large B cells & - & PHA & $105 \pm 2 !$ & $969 \pm 102$ \\
\hline Large B cells & - & Namalva (factor) & $41,089 \pm 3,178$ & $22,158 \pm 484$ \\
\hline Large B cells & - & T-ALL & $58,880 \pm 5,049$ & $19,106 \pm 750$ \\
\hline Large B cells & - & $3 \mathrm{~B} 3$ & $11,178 \pm 352$ & $3,871 \pm 442$ \\
\hline Large B cells & - & $3 \mathrm{~B} 3$ + Namalva (factor) & $55,890 \pm 3,715$ & $33,813 \pm 1,275$ \\
\hline Large B cells & - & $3 \mathbf{B} 3+\mathrm{T}-\mathrm{ALL}$ & $5 \dot{4}, 483 \pm 1,378$ & $19,750 \pm 628$ \\
\hline
\end{tabular}




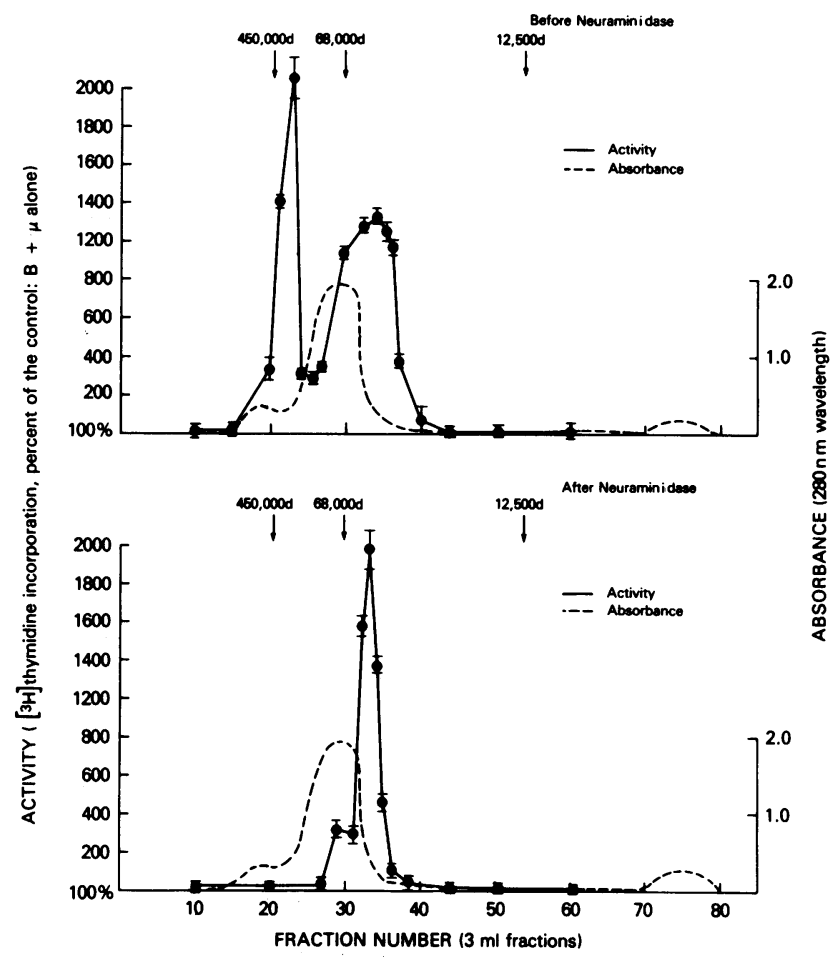

Figure 1. G-100 column of Namalva (factor) before and after neuraminidase treatment. Namalva (factor) was concentrated 100 times and then run over the G-100 column. Fractions were collected and assayed for BCGF activity (- - - ) using the anti- $\mu$ costimulatory assay and absorbance at $280 \mathrm{~nm}(---)$. Molecular weight standards are shown above the small arrows; $d=$ mol wt.

responsible for the high molecular weight peak, neuraminidase may be somehow preventing this aggregation. Fig. 2 indicates the peaks of BCGF activity obtained when the active fractions of Namalva (factor) from the G-100 column (Fig. 1) were focused in a preparative bed of Pevicon with ampholytes. The isoelectric points, before neuraminidase treatment, are 6.7 and 7.8 , similar to the isoelectric points of 3B3-produced BCGF (9). Neuraminidase-treated Namalva (factor) has two distinct isoelectric points, 7.1 and 7.8. Namalva (factor) purified by ion exchange chromatography, G-100 sieving, and then isoelectric focusing, was iodinated with the Bolton-Hunter reagent. Fig. 3 shows the autoradiography of $1^{125}$-labeled Namalva (factor) in a $10 \%$ SDS-polyacrylamide gel. The molecular weight of iodinated Namalva (factor) is $\sim 60,000$ without a significant shift in migration of the band after reduction with 2-mercaptoethanol. Fig. 4 shows that this iodinated protein has isoelectric points of 6.1 and 7.6, similar to the isoelectric points of uniodinated Namalva (factor). Furthermore, Table VI shows that the iodinated Namalva (factor) retains some BCGF activity. This suggests that the iodinated protein is in fact the BCGF produced by Namalva and not a protein from the media.

\section{Discussion}

In the present study, we have demonstrated the production of BCGF or BCGF-like activity by EBV-positive as well as EBVnegative $B$ cell lines. We have also demonstrated the ability of

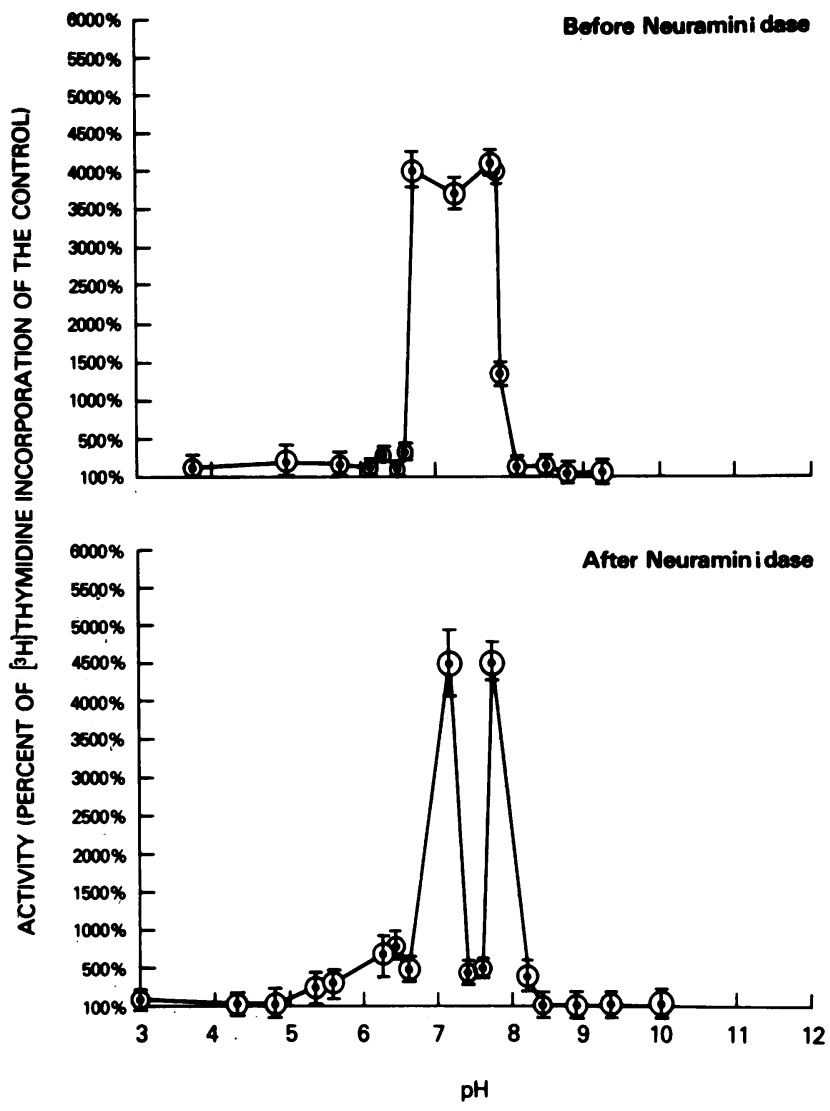

Figure 2. Isoelectric focusing of the active fractions from the G-100 column of Namalva (factor) before and after neuraminidase treatment. Active fractions from G-100 sizing were placed in a bed of Pavikon and exposed to an electrical current at a constant power of 5 $\mathrm{W}$ until $1,000 \mathrm{~V}$ was attained. The bed was sliced, and individual fractions were dialyzed and then assayed for $\mathrm{pH}$ and BCGF activity $(\bullet)$ in an anti- $\mu$ costimulator assay.

certain B cell lines to use this BCGF. These observations are of potential importance because BCGF is a lymphokine that is generally thought of as $T$ cell derived and that modulates $B$

\section{Controls 12}

mol wt

$92,000 \longrightarrow$

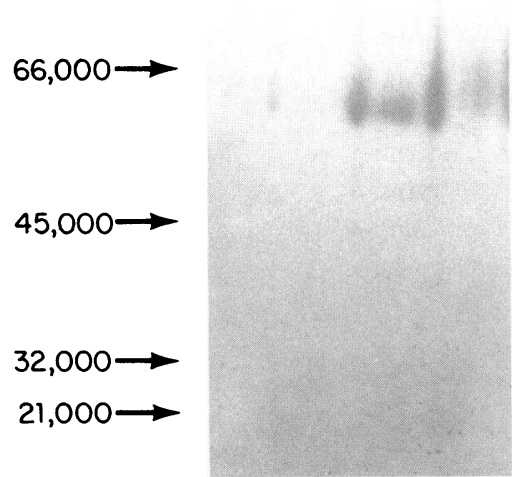

Figure 3. SDS-polyacrylamide gel electrophoresis of Namalva (factor) purified by ion exchange chromatography, G-100 sieving, and isoelectric focusing and then iodinated with the Bolton-Hunter reagent. 


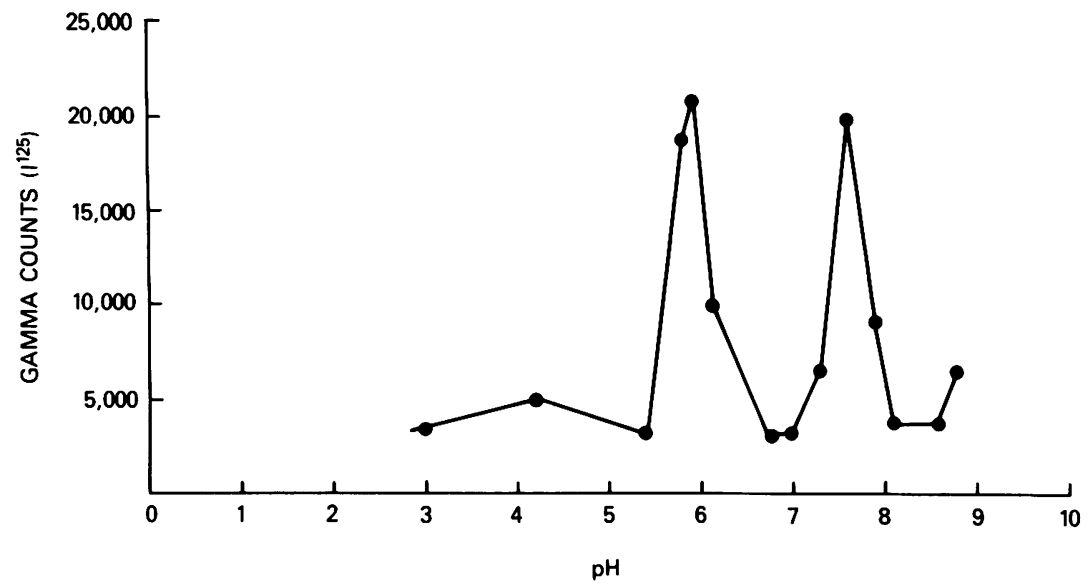

Figure 4. Isoelectric focusing of $\mathrm{I}^{125}$-labeled purified Namalva (factor) using a $6 \%$ acrylamide gel. Focusing was performed at a constant power of $5 \mathrm{~W}$ until $800 \mathrm{~V}$ was attained. The gel was then sliced and individual slices assayed in a gamma counter. cell function by inducing the proliferation of preactivated $B$ cells $(2,3,10)$. It is considered to be an essential requirement for the sustained growth of B cells in vitro and most likely in vivo $(5,22)$. That B cells can elaborate this growth factor has important implications in understanding the potential for autonomous B cell growth independent of $\mathrm{T}$ cell influences, which may occur normally in areas such as the spleen or lymph nodes in which B cells exist at a very high density with relatively few $\mathrm{T}$ cells present. Autonomous B cell growth certainly occurs with B cell malignancies. The ability to produce BCGF for autoutilization may contribute to the ability of a malignant line to grow indefinitely. In addition, BCGF produced by these malignancies may act on normal B cells, thus contributing to the diffuse immunologic abnormalities seen with these malignancies. Perhaps only a small subpopulation of B cells can produce BCGF for this type of function, of which Namalva may be an extension. On the other hand, normal B cells may not be able either to produce or secrete the lymphokine, and Namalva (factor) may merely be the result of a malginant cell trying to express genes that cannot be expressed normally.

Table VI. BCGF Activity of Iodinated Namalva (Factor) Assayed on SAC*-stimulated Unfractionated B Cells

\begin{tabular}{lcc}
\hline Factor & Beta counts & Gamma counts \\
\hline None & $1,907 \pm 5$ & \\
PHA & $449 \pm 52$ & \\
Namalva (factor)§ & $8,848 \pm 357$ & \\
I $^{125}$-labeled Namalva factor§ & $7,228 \pm 247$ & $3,328 \pm 59$ \\
& $(5,160)^{11}$ & $(2,068) \pi$
\end{tabular}

* SAC used at 1:25,000 dilution.

$\ddagger$ PHA used at $1 \mu \mathrm{g} / \mathrm{ml}$.

$\S$ Namalva (factor) and $I^{125}$-labeled Namalva (factor) were used at $25 \% \mathrm{vol} / \mathrm{vol}$.

"From below, 7,228 - 2,068 $=5,160$.

I $20 \lambda$ of $\mathrm{I}^{125}$-labeled Namalva (factor) was placed in hydrofluor. Beta counts/1 min were measured using a model LS9000 (Beckman Instruments, Inc., Fullerton, CA) set to an energy window of 0-397, then gamma counts/1 min were measured using a gamma system (Beckman Instruments, Inc); $(23,000 / 37,627)(3,328)=2,068$.
To our knowledge, no other human B cell line has been demonstrated to produce BCGF. The autostimulatory activity produced by EBV-transformed B cell lines described by Blazar et al. (6) and Gordon et al. $(7,8)$ was not characterized as a distinct or unique lymphokine. Yoshizaki et al. (23) have demonstrated BCDF activity in a clone of the BCDF-responsive, EBV-transformed line CESS. In the murine system, ClarkLewis et al. have found a B cell line, WEHI-231.1, which produces IL 1, T cell-replacing factor, colony-stimulating factor, and $P$ cell-stimulating factor activity (24). The supernatant from WEHI-231.1 can enhance the proliferation of mouse B cells (24). However, IL 1, which is contained in the supernatant, has been demonstrated to enhance the proliferation of anti- $\mu$ activated B cells or to synergize with BCGF to further enhance proliferation (18).

In these studies, we attempted to distinguish Namalva (factor) from the other lymphokines that are known to be capable of enhancing B cell proliferation. Namalva (factor) failed to demonstrate IL 1 activity in a standard IL 1 assay using mouse thymocytes (12). Furthermore, it has a molecular weight of $\sim 60,000$ while IL 1 has a molecular weight of 15,000 (25). However, IL 1 produced by a murine cell line has been found to have a molecular weight between 50,000 and 89,000 by gel filtration chromatography (26).

Namalva (factor) can be distinguished from IL 2 by physiologic as well as biochemical criteria. It failed to sustain the proliferation of HT-2. In addition, it has a much higher molecular weight $(\sim 60,000$ vs. 15,500$)$ than IL $2(27)$ and a more alkaline isoelectric point (6.7-7.8 vs. $3.5-4.5)(28)$.

The possibility that Namalva (factor) may be an interferon was a major concern since interferon can enhance the proliferation of SAC-activated B cells (20). However, no antiviral activity could be demonstrated by the factor on human amniotic cells. Biochemically, Namalva (factor) cannot be distinguished from all interferons because of the wide range in their reported molecular weights and isoelectric points (29). However, it is clear that Namalva (factor) described here is biochemically different from the 18,000 -mol-wt interferon produced by Namalva infected with Sendai virus (30). Finally, Pickering et al. (30) confirm our finding that uninfected Namalva fails to produce any interferon.

Namalva (factor) appears to be a BCGF or BCGFs, although it is not entirely clear whether it is a physiologically important 
lymphokine or merely a cellular byproduct of an EBV-transformed malignant cell line. EBV particles have been shown to range from a molecular weight of 290,000 to 28,000 (31). While there is no absolute way of determining its importance, several lines of evidence argue against Namalva (factor) being a trivial byproduct of EBV. First, Namalva contains very little EBV DNA and does not secrete EBV particles (G. Armstrong, personal communication). Second, several known EBV-transformed cell lines such as BALM-1 and NALM-6 do not generate BCGF-like activity after mitogen stimulation. Finally, BALL-1 has been successfully cloned with the result that some clones (Ball-1S) produced large amounts of BCGF-like activity while others (Ball-1A5) produced no BCGF activity but enhanced their proliferation in response to Namalva (factor) or other types of human BCGF (Table V) (J. L. Ambrus and A. S. Fauci, unpublished data).

Physiologically, Namalva (factor) enhanced the proliferation of large, presumably activated B lymphoytes (12) more than small resting B lymphocytes costimulated with anti- $\mu$. It, however, can clearly act on both of these B cell populations. It was found to be similar to the BCGF produced by T-ALL both physiologically and biochemically (data not shown) but different from the BCGF produced by $3 \mathrm{~B} 3$ both physiologically (acting preferentially on large rather than small costimulated $B$ cells) and biochemically (Namalva [factor] molecular weight $\sim 60,000$ vs. that of $3 B 3, \sim 20,000$ ). Namalva (factor) is somewhat analogous to the late acting BCGF II described in the murine system by Swain et al. (32) and in the human system by Okada et al. (33).

Large quantities of Namalva (factor) must be purified to determine its exact biochemical characteristics so that it may be compared with other known lymphokines. Purification will also allow further exploration of the physiologic effects of the factor on various $B$ cell populations and of the interaction of this factor with other BCGF. Ultimately, with the purification of the factor and the receptor(s) with which it interacts, we will be able to determine if normal B cells can produce the same factor and to see the conditions under which normal and malignant $B$ cells produce the factor.

\section{Acknowledgments}

The authors would like to thank Drs. Debra L. Bowen, Eric J. Brown, Joseph L. Butler, Theresa L. Gerrard, Gary Gilliland, Marion Peters, and James Shelhammer for their kind assistance and helpful discussions and Ms. Ann C. London for her editorial assistance.

\section{References}

1. Andersson, J., and F. Melchers. 1981. T cell-dependent activation of resting B cells: requirement for both nonspecific unrestricted and antigen-specific Ia-restricted soluble factors. Proc. Natl. Acad. Sci. USA. 78:2497-2501.

2. Dutton, R. W. 1975. Separate signals for the initiation and differentiation in the B cell response to antigen. Transplant. Rev. 23: 66-77.

3. Yoshizaki, K., T. Nakagawa, T. Kaieda, A. Muraguchi, Y. Yamamura, and T. Kishimoto. 1982. Induction of proliferation and Ig production in human B leukemic cells by anti-immunoglobulins and $\mathrm{T}$ cell factors. J. Immunol. 128:1276-1301.
4. Butler, J. L., A. Muraguchi, H. C. Lane, and A. S. Fauci. 1983. Development of a human T-T cell hybridoma secreting B cell growth factor. J. Exp. Med. 157:60-68.

5. Maizel, A. L., J. W. Morgan, S. R. Mehta, N. M. Kouttab, J. M. Bator, and C. G. Sahasrabuddhe. 1983. Long-term growth of human B cells and their use in a microassay for B-cell growth factor. Proc. Natl. Acad. Sci. USA. 80:5047-5051.

6. Blazar, B. A., L. M. Sutton, and M. Strome. 1983. Selfstimulating growth factor production by B-cell lines derived from Burkitt's lymphomas and other lines transformed in vitro by EpsteinBarr virus. Cancer Res. 43:4562-4568.

7. Gordon, J., S. C. Ley, M. D. Melamed, P. Aman, and N. C. Hughes-Jones. 1984. Soluble factor requirements for the autostimulatory growth of B lymphoblasts immortalized by Epstein-Barr virus. J. Exp. Med. 159:1554-1559.

8. Gordon, J., S. C. Ley, M. D. Melamed, L. C. English, and N. C. Hughes-Jones. 1984. Immortalized B lymphocytes produce B cell growth factor. Nature (Lond.). 310:145-147.

9. Butler, J. L., J. L. Ambrus, Jr., and A. S. Fauci. 1984. Characterization of human B cell growth factor. J. Immunol. 133:251255.

10. Falkoff, R. J. M., L. P. Zhu, and A. S. Fauci. 1982. Separate signals for human B cell proliferation and differentiation in response to Staphylococcus aureus. Evidence for a two signal model of B cell activation. J. Immunol. 129:97-102.

11. Falkoff, R. M., M. Peters, and A. S. Fauci. 1982. T cell enrichment and depletion of human peripheral blood mononuclear cell preparations. Unexpected findings in the functional activities of the separated populations. J. Immunol. Methods. 50:39-49.

12. Muraguchi, A., J. L. Butler, J. H. Kehrl, and A. S. Fauci. 1983. Differential sensitivity of human B cell subsets to activation signals delivered by a monoclonal B cell growth factor. J. Exp. Med. 157: 530-546.

13. Meltzer, M. A., and J. J. Oppenheim. 1977. Bidirectional amplification of macrophage-lymphocyte interactions: enhanced lymphocyte activation factor production by activated mouse peritoneal cells. J. Immunol. 118:77-82.

14. Hooks, J. J., H. Moutsopoulos, S. Geis, N. I. Stahl, J. L. Decker, and A. L. Notkins. 1979. Immune interferon in the circulation of patients with autoimmune disease. N. Engl. J. Med. 301:5-8.

15. Kappler, J., B. Skidmore, J. White, and P. Marrack. 1981. Antigen inducible, $\mathrm{H}-2$ restricted interleukin-2-producing $\mathrm{T}$ cell hybridomas. Lack of independent antigen and H-2 recognition. J. Exp. Med. 153:1198-1214.

16. Langone, J. J. 1980. Radioiodination by use of the BoltonHunter and related reagents. Methods Enzymol. 70:221-243.

17. Laemmli, U. K. 1970. Cleavage of structural proteins during the assembly of the head of bacteriophage T4. Nature (Lond.). 227: 680-685.

18. Kaplan, D. R., T. J. Henkel, V. Braciale, and T. J. Braciale. 1984. Mycoplasma infection of cell cultures: thymidine incorporation of culture supernatants as a screening test. J. Immunol. 132:9-11.

19. Falkoff, R. J. M., A. Muraguchi, J.-X. Hong, J. L. Butler, C. A. Dinarello, and A. S. Fauci. 1983. The effects of interleukin 1 on human B cell activation and proliferation. J. Immunol. 131:801-805.

20. Marrack, P., S. D. Graham, E. Kushmir, J. H. Leibson, N. Roehm, and J. W. Kappler. 1982. Nonspecific factors in B cell responses. Immunol. Rev. 63:33-49.

21. Harada, H., K. Shioiri-Nakano, M. Mayumi, and T. Kawai. 1983. Distinction of two subtypes of human leukocyte interferon (IFN$\alpha$ ) on B cell activation. B cell proliferation by two subtypes of IFN- $\alpha$. J. Immunol. 131:238-243.

22. Howard, M., S. Kessler, T. Chused, and W. E. Paul. 1981. Long-term culture of normal mouse B lymphocytes. Proc. Natl. Acad. Sci. USA. 78:5788-5792. 
23. Yoshizaki, K., T. Nakagawa, K. Fukunaga, L. T. Tseng, Y. Yamamura, and T. Kishimoto. 1984. Isolation and characterization of B cell differentiation factor (BCDF) secreted from a human B lymphoblastoid cell line. J. Immunol. 132:2948-2954.

24. Clark-Lewis, I., J. W. Schrader, Y. Y. Wu, and A. W. Harris. 1982. A B lymphoma cell line produced growth factors for hemopoietic, lymphoid, and mast cells. Cell. Immunol. 69:196-200.

25. Mizel, S. B. 1982. Interleukin 1 and T cell activation. Immunol. Rev. 63:51-72.

26. Lachman, L. B., M. P. Hacker, G. T. Blyden, and R. E. Hondschumacker. 1977. Preparation of lymphocyte activating factor from continuous murine macrophage cell lines. Cell. Immunol. 34: 416-419.

27. Smith, K. A., M. F. Favata, and S. Oroszlan. 1983. Production and characterization of monoclonal antibodies to human interleukin 2: strategy and tactics. J. Immunol. 131:1808-1815.

28. Farrar, J. J., M. Howard, J. Fuller-Farrar, and W. E. Paul. 1983. Biochemical and physiochemical characterization of mouse B cell growth factor: a lymphokine distinct from interleukin $2 . J$. Immunol. 131:1838-1842.

29. Stewart, W. E. II. 1979. The Interferon System. SpringerVerlag, New York, Inc., New York. 134-183.

30. Pickering, L. A., L. H. Kronenberg, and W. E. Stewart II. 1980. Spontaneous production of human interferon. Proc. Natl. Acad. Sci. USA. 77:5938-5942.

31. Polymink, M., R. Pritchett, and E. Kieff. 1976. Proteins of Epstein-Barr virus. I. Analysis of the polypeptides of purified enveloped Epstein-Barr virus. J. Virol. 17:935-949.

32. Swain, S. L., M. Howard, J. Kappler, P. Marrack, J. Watson, R. Booth, G. D. Wetzel, and R. W. Dutton. 1983. Evidence for two distinct classes of murine $B$ cell growth factors with activities in different functional assays. J. Exp. Med. 158:822-835.

33. Okada, M., N. Sakaguchi, N. Yoshimura, H. Hara, K. Shimizu, N. Yoshida, K. Yoshizaka, S. Kishimoto, Y. Yamamura, and T. Kishimoto. 1983. B cell growth factors and B cell differentiation factor from human $T$ hybridomas. Two distinct kinds of $B$ cell growth factor and their synergism in B cell proliferation. J. Exp. Med. 157:583-590. 